\title{
HYPOGLYCAEMIA IN THE NEWBORN
}

\author{
Orhideja Stomnaroska ${ }^{1}$, Elizabeta Petkovska ${ }^{1}$, Sanja Ivanovska ${ }^{1}$, Snezana Jancevska ${ }^{1}$, Dragan Danilovski ${ }^{2}$ \\ ${ }^{1}$ University Clinic for Gynaecology and Obstetritics, Medical Faculty Skopje, Macedonia \\ ${ }^{2}$ Institute for Epidemiology and Statistics, Medical Faculty Skopje, Macedonia
}

Corresponding author: Orhideja Stomnaroska, University Clinic for Gynaecology and Obstetritics, Medical Faculty Skopje, Vodnjanska BB, 1000 Skopje, Macedonia; stomnaroskao@yahoo.com

The authors have no conflict of interest.

This manuscript or a similar one was not submitted or published in any other journal.

\section{ABSTRACT}

Aim: Severe neonatal hypoglycaemia (HG) leads to neurologic damage, mental retardation, epilepsy, impaired cardiac performance and muscle weakness. The aim was to assess the frequency and severity of $\mathrm{HG}$ in a population of newborns.

Patients and methods: We investigated 739 patients with neonatal hypoglycaemia (HG) (M:F=370:369) born at the University Clinic for Gynaecology and Obstetritics in Skopje in the period 2014-2016 and treated at the neonatal intensive care unit (NICU). 1416 babies were treated in the same period in NICU, and HG was observed in $52.18 \%$. The birth weight was dominated by children with low birth weight: very low birth weight $(\mathrm{VLBW})(<1500 \mathrm{~g}) 253$ children, $(34,23 \%)$, low birth weight (1500-2500g) 402 (54.39\%), appropriate for gestational age (AGA) $78(10.55 \%$ ), and high birth weight $(>4000 \mathrm{~g}) 6$ babies $(0.81 \%)$. The gestational age was also dominated by children with low gestational age: gestational week $(\mathrm{GW}) 20-25$ four children $(0.54 \%), 26-30 \mathrm{GW}$ 133 babies (17.99\%), 31-35 GW472 (63.87\%), and 36-40 GW130 neonates (17.59\%).

241 mothers $(32.61 \%)$ have had an infection during pregnancy, 82 preeclampsia or eclampsia (11.09\%), 20 diabetes mellitus (2.70\%), 78 placental situations (placenta previa, abruption) $(10.55 \%)$. In this study 47 babies $(6.35 \%)$ with HG and co-morbidities died.

There was a significant positive correlation between HG birth weight $(\mathrm{p}<0.01)$, gestational age $(\mathrm{p}<0.05)$, and the lowest Apgar score $(\mathrm{p}<0.01)$. Neonatal deaths were significantly correlated with GA $(p>0,01)$, co-morbidities of the mothers $(p>0,05)$ but not with the birth weight $(p>0,05)$. In contrast, a significant positive correlation was found between convulsions and body weight $(p<0.05)$. The lowest Apgar score was positively correlated with the gestational age $(0.01)$, but not with the birth weight (0.05).

Conclusion: Low birth weight, low gestational age, maternal risk factors, hypoxic-ischemic encephalopathy and neonatal infections are associated with HG and are a significant factor in overall neonatal mortality. Those results indicate that diminishing the frequency of the neonatal HG and the rates of neonatal mortality requires complex interaction of prenatal and postnatal interventions.

Key words: neonatal hypoglycaemia, co-morbidities, mortality. 


\section{INTRODUCTION}

There is well documented increased risk of $\mathrm{HG}$ and seizures in newborn babies [1-3]. Both conditions increase long term invalidity and neonatal mortality. Neonatal HG and seizures are especially frequent in neonatal intensive care units (NICU): $10-25 \%$ of babies manifest seizures, $15 \%$ of newborns with seizures die, while and $35-40 \%$ will have significant neurological consequences [3].

There are multiple other factors that predispose for HG: infections, intracranial hemorrhage, hypoxic-ischemic encephalopathy (HIE) $(\sim 50 \%$ of the patients). Some of them are the cause for neonatal HG: birth trauma, CNS malformations, metabolic disorders $[1,3]$.

Timely and appropriate treatment will hinder a poor neurological outcome (Howden 4, Merhta; 5). Persistent and recurrent severe hypoglycaemia results in worst outcomes $[3,6]$.

We evaluated 739 babies in the NICU at the Clinic for Gynecology and Obstetrics in Skopje, Macedonia.

\section{PATIENTS AND METHODS}

This study was done in the NICU of the UCGO at the Medical Faculty Skopje, Macedonia. The study was approved by the Ethics Committee at the Medical faculty Skopje.

This is the applied classification of neonatal HG: capillary blood glucose $(\mathrm{CBG})$ values were considered normal when $\geq 2.5 \mathrm{mmol} / \mathrm{l}$, or $\mathrm{HG}$ was mild (2.2-2.4 mmol/l), moderate (1.6-2.1 mmol/1) or severe HG $(<1.6 \mathrm{mmol} / \mathrm{l})(1)$. There were multiple measurements of CBG (from the first hour after birth, than consecutively the $3^{\text {rd }}, 6^{\text {th }}$ hour of life, and/or until the resolution of the $\mathrm{HG}$ episode).

The seizures were investigated by clinical examination, laboratory results, and/or imaging (ultrasound).

The Diagnosis of birth asphyxia HIE was done at the basis of criteria given by the American Academy of Pediatrics and the American College of Obstetricians and Gynecologists [1]: 1) Profound metabolic or mixed acidemia $(\mathrm{pH}<7.00)$ in umbilical arterial blood. 2) Apgar score of 0-3>5 minute after birth. 3) Signs of neonatal encephalopathy (seizures, coma, or hypotonia), 4) Multiple organ involvement (kidney, lungs, liver, heart, intestines). Almost all the babies were breast-fed, occasionally formulas were used.

Clinical examination, blood cell count, $\mathrm{C}$ reactive protein, and positive blood culture resulted in the diagnosis of sepsis. Pulmonary infections were assessed clinically and confirmed by microbiological analysis of the deep tracheal aspiration. The clinical suspicion for existence of intracranial hemorrhage was confirmed with US or CT scan.

ARCHITECT plus c4000, Integra 400 system was used for biochemical analysis.

The statistical analysis included non-parametric statistics (Spearman rank test) as the distribution of variables was not normal.

\section{RESULTS}

In this study, we investigated 739 patients with neonatal hypoglycaemia $(\mathrm{HG})(\mathrm{M}: \mathrm{F}=370: 369)$ born at the University Clinic for Gynaecology and Obstetrics (UCGO) in Skopje in the period 29.9.2014-28.10.2016 and who were treated at the neonatal intensive care unit (NICU). The total hospitalized in this period was 1416 , which amounts to $52.18 \%$ of the patients having HG. The birth weight was dominated by children with low birth weight: very low birth weight $(\mathrm{VLBW})(<1500 \mathrm{~g})$ 253 children, $(34,23 \%)$, low birth weight (1500$2500 \mathrm{~g}) 402$ (54.39\%), appropriate for gestational age (AGA) $78(10.55 \%)$, and high birth weight $(>4000 \mathrm{~g}) 6$ babies $(0.81 \%)$.

The gestational age was also dominated by children with low gestational age: gestational week (GW) 20-25 - 4 children $(0.54 \%), 26-30 \mathrm{GW}$ - 133 babies (17.99\%), 31-35 GW - 472 (63.87\%), and 36-40 GW - 130 neonates $(17.59 \%)$.

The delivery was Caesarean in $450(60.89 \%)$ babies, while $289(39.10 \%)$ neonates were delivered virginally.

In this series there were no inborn errors of metabolism. Asymptomatic hypoglycaemia was found in 550 (25.57\%) children, while symptomatic HG with seizures was observed in 189 (74.43\%).

241 mothers (32.61\%) have had an infection during pregnancy, 82 preeclampsia or eclampsia (11.09\%), 20 diabetes mellitus $(2.70 \%), 78$ placental situations (previa, abruption)(10.55\%).

In this group, 145 babies had (19.62\%) hypoxic-ischemic encephalopathy, 139 had infections (18.80\%), 30 intracranial hemorrhage $(4.059 \%)$, and 45 hypocalcemia (6.08\%)(Fig.3).

47 babies $(6.35 \%)$ with HG and co-morbidities died. Thus neonatal HG has in important contributing role in the general neonatal mortality.

There was a significant correlation between $\mathrm{NH}$ birth weight (at the level of 0.01), gestational age (at the level of 0.05), and the lowest Apgar 
score (at the level of 0.01). Interestingly, there wasn't a positive correlation between the lowest glycaemia and convulsions ( $\mathrm{p}>0.05)$, as well as with the gestational age $(\mathrm{p}>0.05)$ maternal co-morbidities $(p>0.05)$. Neonatal deaths were significantly correlated with GA $(\mathrm{p}>0.01)$, maternal co-morbidities $(\mathrm{p}<0.05)$ but not with the birth weight ( $p>0.05$ ). In contrast, significant positive correlation was found between convulsions and body weight $(\mathrm{p}<0.05)$. The lowest Apgar score was positively correlated with the gestational age $(0.01)$, but not with the birth weight $(\mathrm{p}>0.05)$.

\section{DISCUSSION}

Avoiding neonatal HG is critical as even transient moderate HG can result in some neurological sequelae [7]. In spite of plentiful research, the nadir glucose concentrations and the duration of $\mathrm{HG}$ that causes brain damage in new-borns are not adequately elucidated $[1,3]$. Moreover, the specific value of serum glucose for hypoglycaemia is not universally accepted [8-12]. The title "is the sixty the new forty" ( $\mathrm{mg} / \mathrm{dl})$ is a striking example of the lack of solid evidence in defining the neonatal HG [13].

Among 1416 babies treated in the same period in NICU, we observed HG in $52.18 \%$. In Japan, among the neonates born at 35-36 week of gestation $>80 \%$ of the admissions to the NICU after birth were due to apnea or HG [14]. USA reported the HG frequency is estimated to 1.3-3 per 1000 live births. Other publications [15-20] have observed an incidence between $7-11 \%$. In Harris county, USA, an incidence of 1-3.5/1000 live birth was reported $[1,18]$. NICU have high incidence of HG: 10-25\% [21]. The difference in the frequency in the neonatal HG between this study and others can be contributed to the population studied: NICU or delivery ward, and the population studied Aga non-AGA, normal birth weight or various degrees of LBW.

In our study the prevalent number of babies had not AGA, but had some form of LBW: $88.62 \%$. As could be expected there was a significant correlation between $\mathrm{NH}$ birth weights $(\mathrm{p}<$ 0.01 ). Interestingly, significant positive correlation was found between convulsions and body weight $(p<0.05)$. In a seminal study, children born with a birth weight $<1850 \mathrm{~g}$ had worse development at 18 months [22]. Adamkin $(2011 ; 23)$ has found that LGA, SGA, IUGR are at special risk. Increased BW was also found to be HG risk factors in babies in whom the mother did not have DM [24].
Gestational age among children with HG was also dominated by babies with low gestational age $-82.40 \%$. This finding is characteristic for developing countries ( 1, NCHS). It is of note that there was a significant correlation between $\mathrm{HG}$ and gestational age $(\mathrm{p}<0.05)$.

There was a significant correlation between $\mathrm{HG}$ and the lowest Apgar score $(\mathrm{p}<0.01)$. The lowest Apgar score was positively correlated with the gestational age $(p<0.01)$, but not with the birth weight $(p>0.05)$. Interestingly, there was not a positive correlation between the lowest glycaemia and convulsions $(p>0.05)$. Asymptomatic hypoglycaemia was found in $550(25.57 \%)$ children, while symptomatic HG with seizures was observed in $189(74.43 \%)$.

In 145 babies $(19.62 \%)$ hypoxic-ishemic encephalopathy (HIE) was diagnosed. Other publications have also observed that HIE was also the most frequent factor $[15,25,26]$. This condition may aggravate the role of $\mathrm{HG}$ in causing brain damage. HIE was observed to be the leading factor in neonatal convulsions [15, 27, 28].

Adamkin $(2011 ; 23)$ has found that and infants of diabetic mothers (DM) are at special risk. In this study 9 mothers were diabetic (type 1 or 2), while 11 mothers had gestational diabetes $(2.70 \%)$. Maternal risk factors are well known to contribute to neonatal $\mathrm{HG}$ and neonatal mortality $[1,3]$.

Neonatal infections were common among babies with seizures in this study: 139 had infections $(18.80 \%)$. This observation was shared in other publications in which new-born infections ranged between $24.5 \%$ [25], 28.2 [21].

In this study intracranial hemorrhage was observed in 30 patients $(4.05 \%)$. Other studies have also reported a high percentage of intracranial bleeding: $6.9 \%-9.0 \%[2,15,23]$. This study also observed 45 babies with hypocalcemia (6.08\%), which is a reported common metabolic disturbance in new-borns [3, 21].

The overall mortality remains high, especially in children with co-morbidities. HIE and infections are the most common leading causes of death. The mortality rates ranged between 9 and $14.7 \%$ [3, 15]. 47 babies $(6.35 \%)$ with $\mathrm{HG}$ and co-morbidities died. Thus, neonatal HG has a contributing role in the general neonatal mortality. Neonatal deaths were significantly correlated with GA ( $p>0.01)$, maternal co-morbidities $(p>0.05)$ but not with the birth weight ( $p>0.05$ ).

In general, differences in the observed frequency of various co-morbidities and outcomes in children with $\mathrm{HG}$ originate from the different 
types of new-born populations: full-term versus pre-term, LBW versus ABW, patients from neonatal wards versus NICU.

Lowering the frequency of neonatal $\mathrm{HG}$ would lower the neonatal mortality. Prematurity remains a main risk for neonatal $\mathrm{HG}$ and the main cause of death in newborns: prematurity-related deaths are $51 \%$ of the deaths among children less than 5 years of age (WHO, 2015) [29]. In USA the overall neonatal mortality is 4.2 (NCHS) [30], perinatal mortality in Macedonia is 7.4/1000 live births [31]. In addition, the under age 5-year mortality was higher in Macedonia than in many neighboring countries [29, 31]. Lowering the frequency of neonatal $\mathrm{HG}$ would lower the neonatal mortality.

In conclusion, neonatal HG is frequent metabolic event in new-borns. Neonatal HG is an important co-factor in neonatal mortality. This study strongly recommends the need for comprehensive, team approach in the efforts to lower the rates of prematurity, low birth weight, birth asphyxia and infections. An improvement in the follow-up of pregnancies and mothers is strongly needed and recommended.

\section{REFERENCES}

1. Sperling M. Hypoglycaemia. In: Nelson Textbook of Pediatrics, Elsevear, Philadelphia, 2016; 655-669.

2. Loman AM, ter Horst HJ, Lambrechtsen FA, Lunsing RJ. Neonatal seizures: aetiology by means of a standardized work-up. Eur J Paediatr Neurol. 2014;18(3):360-7.

3. WHO ref. number $\mathrm{WHO} / \mathrm{CHD} / 97.1 / \mathrm{WHO} /$ MSM/97.1 Hypoglycaemia in the newborn. Geneva: World Health Organization. 1997 4, 19.

4. Hawdon JM, Ward Platt MP, Aynsley-Green A. Prevention and management of neonatal hypoglycemia. Arch Dis Child Fetal Neonatal Ed. 1994;70(1):F60-F64.

5. Mehta A. Prevention and management of neonatal hypoglcaemia. Arch Dis Child. 1994;70(1):F54-F65.

6. Menni F, de Lonlay P, Sevin C, et al. Neurologic outcomes of 90 neonates and infants with persistent hyperinsulinemic hypoglycemia. Pediatrics. 2001;107:476-479.

7. Lucas A, Morley R, Cole TJ. Adverse neurodevelopmental outcome of moder- ate neonatal hypoglycaemia. Br Med J. 1988;297(6659):1304-1308.

8. Bonacruz GL, Arnold JD, Leslie GI, Wyndham L, Koumantakis G. Survey of the definition and screening of neonatal hypoglycaemia in Australia. J Paediatr Child Health. 1996;32(4):299-301.

9. Laptook A, Jackson GL. Cold stress and hypoglycemia in the late preterm ("near-term") infant: impact on nursery of admission. Semin Perinatol. 2006;30(1):24-27.

10. Rozance PJ, Hay WW Jr. Hypoglycemia in newborn infants: features associated with adverse outcomes. Biology of the Neonate. 2006;90:74-86.

11. Rozance PJ, Hay, WW Jr. Describing hypoglycemia - definition or operational threshold? Early Hum Dev. 2010; 86(5): 275-280.

12. Faustino EV, Hirshberg EL, Bogue CW. Hypoglycemia in critically ill children. J Diabetes Sci Technol. 2012;6(1):48-57.

13. Adamkin DH, Polin R. Neonatal hypoglycaemia: is the 60 the new forty? The questions remain the same. Journal of Perinatology 2016; 36: 10-12.

14. Ishiguro A, Namai Y, Ito YM. Managing "healthy" late preterm infants. Pediatr Int. 2009;51(5):720-725.

15. Sabzehei MK, Basiri B, Bazmamoun H. The Etiology, Clinical Type, and Short Outcome of Seizures in NewbornsHospitalized in Besat Hospital/Hamadan/ Iran. Iran J Child Neurol. 2014;8(2):24-8.

16. Mwaniki M, Mathenge A, Gwer S, Mturi N, Bauni E, Newton CR, et al. Neonatal seizures in a rural Kenyan District Hospital: aetiology, incidence and out come of hospitalization . BMC Medicine. 2010;8(16).

17. Sheth RD, Hobbs GR, Mullett M. Neonatal seizure: Incidence, onset and etiology by gestational age. J Perinatol. 1999;19(1):40-3.

18. Saliba RM, Annegera Jf, Waller DK, Tyson JE. Incidence of Neonatal seizures in harris county. American Journal of epidemiology. 2000;150(7):763-9.

19. Udani V. Long-term prognosis of neonatal seizure - where are we? Indian Pediatr. 2008;45(9):739-41.

20. Tan JH, Poon WB, Lian WB, Ho SK. A Comparison of the Short-term Morbidity and Mortality Between Late Preterm and 
Term Newborns. Ann Acad Med Singapore. 2014;43(7):346-54.

21. Faiz N, Malik M, Azam M, Afzal U. Etiology and type of neonatal seizures. Ann Pak Inst Med Sci. 2009;5(2):77-86.

22. Lucas A, Morley R, Cole TJ,. Adverse neurodevelopmental outcome of moderate neonatal hypoglycaemia. Br Med J 1988; 297: 13041308.

23. Adamkin DH. Postnatal glucose homeostasis in late preterm and term infants. Pediatrics. 2011; 127:575-579.

24. Wiessmann-Brenner A, Simchen MJ, Zilberberg E, Kalter A, Weisz B, Achiron R, Dulitzky M. Maternal and neonatal outcomes in of large for gestational age pregnancies. Acta Obstet Gynecol Scand 2012; 91: 844-849.

25. Digra SK, Gupta A. Prevalence of seizures in hospitalized neonates. JK Science. 2007;9(1):27-9.

26. Tekgul H, Gauvrea K, Soul J, Murphy L, Robertson R, stewart J, et al. The current etiology profile and neurodevelopmental outcome of seizures in term newborn infants. Pediatrics. 2006;117(4):1270-80.
27. Ronen GM, Penney S, Andrew W. The epidemiology of clinical neonatal seizure in new found land, a populationbased study. J Pediatr. 1999;134(1):71-75.

28. Arpino C, Domizio S, Carrieri MP, Brescianini DS, Sabatino MH, Curatolo P. Prenatal and perinatal determinants of neonatal seizures occurring in first week of life. Abs J child Neurol . 2001;16(9):651-6.

29. World Health Organization: WHO. www. who.int/WorldHealthOrganization. Global health observatory. Accessed November 27, 2016.

30. National Center for Health Statistics: Health, United States, 2013: with special feature on prescription drugs, Hyattsville, MD, 2014, Department of Health and Human Services, Tables 11, p. 98, and 17, p. 71.

31. Institute of Public Health of Republic of Macedonia. http://iph.mk/wpcontent/uploads/2015/03/Spoen-izvestaj-novo-sosodrzina-i-naslovnaso-CIP.pdf. Accessed November 27, 2016.

32. Tasic V, Danilovski D, Gucev Z. The Health Care System of Macedonia. J Pediatr. 2016;177S:S127-S137.

\section{ХИПОГЛИКЕМИЈА НА НОВОРОДЕНИТЕ}

Орхидеја Стомнароска ${ }^{1}$, Елизабета Петковска ${ }^{1}$, Санја Ивановска ${ }^{1}$, Снежана Јанчевска ${ }^{1}$, Драган Даниловски

1 Универзитетска Клиника за гинекологија и акушерство, Медицински факултет Скопје, Македонија

2 Институт за епидемиологија и статистика, Медицински факултет Скопје, Македонија

\section{Резиме}

Длабоката неонатална хипогликемија (ХГ) резултира во невролошко оштетување, ментална ретардација, епилепсија, намалена срцева моќност и мускулна слабост. Целта на трудот е да се утврдат фреквенцијата и тежината на ХГ кај новородени деца во неонатална интензивна нега. Анализирани се 739 бебиња со неонатална хипогликемија (XГ) (M:F=370:369) родени на Универзитетската клиника за гинекологија и акушерство во Скопје во двегодишен период и лекувани на одделот за интензивна нега. Во истиот период третирани се 1416 деца, а ХГ е опсервирана кај 52.18\%. Доминираа деца со намалена родилна тежина: многу ниска родилна тежина $(\mathrm{VLBW})(<1500 \mathrm{~g}) 253$ деца, $(34,23 \%)$, ниска родилна тежина (1500-2500g) $402(54.39 \%)$. Тежина соодветна за возраста (AGA) имаа $78(10.55 \%)$, а деца со висока родилна тежина $(>4000 \mathrm{~g})$ беа $(0.81 \%)$. Доминираа деца со намалена гестациска возраст (недела) (ГН) 20-25 кај четири деца (0.54\%), 26-30 ГН кај133 бебиња (17.99\%), 31-35 ГН кај 472 (63.87\%), и 36-40 ГН кај 130 новородени (17.59\%). 
241 мајки (32.61\%) имаа инфекција за време на бременоста, 82 прееклампсија и еклампсија (11.09\%), 20 диабетес мелитус (2.70\%), 78 плацентални неправилности (placenta previa, abruption) (10.55\%). 47 деца (6.35\%) со ХГ и ко-морбидности завршија летално.

Постоеше сигнификантна позитивна статистичка корелација меѓу ХГ и родилната тежина $(п<0.01)$, гестациската недела на раѓање $(п<0,05)$, и нискиот Апгар скор $(п<0,01)$. Неонаталните смртни исходи беа сигнификантно поврзани со гестациската возраст (p>0,01), ко-морбиднотите кај мајката $(п>0,05)$, но не и со родилната тежина $(\mathrm{p}>0,05)$. Сигнификантна позитивна корелација е најдена помеѓу конвулзиите и родилната тежина $(п<0,05)$. Нискиот Апогар скор беше позитивно корелиран со гестациската возраст $(\Pi>0,01)$, но не и со родилната тежина $(\Pi>0,05)$.

Ниска родилна тежина, мајчините фактори на ризик, хипооксично-исхемичната енцефалопатија и неонаталните инфекции беа асоцирани со неонаталната ХГ. Истите се сигнификантни фактори за неонаталниот морталитет. Заради ова намалување на фреквенцијата на неонаталната ХГ и намалување на неонаталниот морталитет бара комплетна интерреакција на пренатални и постнатални медицински интервенции.

Клучни зборови: неонатална хипогликемија, неонатален морталитет, ко-морбидности. 